\title{
16. SEISMIC VELOCITIES OF BASALTS FROM DSDP LEG 26
}

\author{
R. D. Hyndman, Department of Oceanography, Dalhousie University, Halifax, Nova Scotia, Canada
}

\section{INTRODUCTION}

Laboratory measurements of seismic velocities of ocean-floor rock are necessary for the interpretation of seismic data in terms of compositions and structures. The association of particular compositions with the refraction- and reflection-determined oceanic-crustal layers has largely been based on the range of compressional velocities found for different rock types. Laboratory measurements must simulate in situ conditions, particularly the in situ pressure (about $0.5 \mathrm{~kb}$ for crustal depths). Birch $(1960,1961)$ has reported velocities for a wide range of continental rocks to $10 \mathrm{~kb}$ pressure. He gives a complete review of previous measurements. More recently, dredged ocean-floor rocks have been measured by Christensen and Shaw (1970), Barrett and Aumento (1970), and Fox et al. (1973). These authors show the seismic data imply compositions of basalt and metabasalt or gabbro for crustal Layers 2 and 3. Christensen and Salisbury (1972), Christensen (1973), Schreiber et al. (1972), and Fox et al. $(1972,1973)$, give velocities for DSDP samples. The basalt samples have a similar range of velocities to the dredged samples, but the least-weathered DSDP samples have higher velocities than those found from most seismic-refraction measurements of Layer 2.

\section{MEASUREMENTS}

Compressional wave velocities were determined on 17 samples to $2-\mathrm{kb}$ pressure. The velocities were measured in the vertical direction in samples $2.5-\mathrm{cm}$ diameter and 4- to $8-\mathrm{cm}$ long using $1-\mu \mathrm{sec}$ pulses applied to and received by $1-\mathrm{mHz}$ barium titanate transducers (Birch, 1960). All samples were at $20-25^{\circ} \mathrm{C}$ and were water saturated. The samples and transducers were jacketed in gum-rubber tubing so that pore pressure should be much less than external pressure. The travel time was determined by comparing, on a dual-trace oscilloscope, the output and input pulses with a variable delay on the input. The delay was determined with a digital counter to $\pm 0.05 \mu \mathrm{sec}$. For some samples the travel time was also determined using a mercury delay line (Birch, 1960). A set of variable-thickness steel discs were used as internal standards and to determine the zero samplethickness delay time. The accuracy of the travel times is about $\pm 0.1 \mu \mathrm{sec}$ or $1-2 \%$ in our samples. Bulk densities were determined by weighing the samples in air and in distilled water and have an accuracy of $1.0 \%$. Pressures are accurate to $2 \%$. Good signals could be obtained consistently only above $0.1 \mathrm{~kb}$.

Velocities of 34 samples also were measured onboard ship at 1 atm using the Hamilton Frame by grinding flat faces on the samples and making good contact with glycerine. Both horizontal and vertical velocities were determined. They have an accuracy of about $3 \%$.

\section{RESULTS}

The laboratory velocities measured as a function of pressure are shown in Table 1 and Figure 1. At upper oceanic-crustal pressures of $0.5 \mathrm{~kb}$ the velocities range from $5.0-6.6 \mathrm{~km} / \mathrm{sec}$. There is a rapid increase in velocity with pressure to $0.5 \mathrm{k}$ as cracks and fractures are closed and then only a small increase to higher pressures. Samples with very large changes at low pressures (such as Sample $254-31-1,111 \mathrm{~cm}$ ) probably are extensively fractured.

Measurements at $1 \mathrm{~atm}$ are of lower accuracy because of the difficulty of making good contact. In the laboratory, 1-atm values were generally $0.2 \mathrm{~km} / \mathrm{sec}$ lower than at $0.5 \mathrm{~kb}$, but there is considerable variability depending on the extent of cracks. This amount must be added to the shipboard values (Table 2) to obtain estimates of in situ velocities. There is no systematic anisotrophy, but measurements in the horizontal and vertical directions differed by up to $4 \%$ which probably represents the extent of inhomogeneities in the sample.

The average velocities are surprisingly high; a mean of $5.84 \mathrm{~km} / \mathrm{sec}$ for 17 samples at $0.5-\mathrm{kb}$ pressure and of $5.35 \mathrm{~km} / \mathrm{sec}$ for 34 samples measured at $1 \mathrm{~atm}$. The latter would be raised to about $5.55 \mathrm{~km} / \mathrm{sec}$ at $0.5 \mathrm{~kb}$. A histogram of the number of samples (laboratory at 0.5 $\mathrm{kb}$ ) versus measured velocity (Figure 2 ) shows that the distribution is skewed with the most common velocity near $6.0 \mathrm{~km} / \mathrm{sec}$. It is puzzling that these velocities and those of other DSDP basalts are so high (also young dredge samples-Christensen and Shaw [1970]) while seismic refraction data give velocities for Layer 2 of 4.5$5.5 \mathrm{~km} / \mathrm{sec}$ (Raitt, 1963; Ludwig et al., 1971; Fox et al., 1973). The answer to the discrepancy may lie in the refraction velocities being representative only of a nearsurface weathered layer.

In the deep hole of Site 257 there is a smooth systematic increase in velocity with depth from an average of $4.2 \mathrm{~km} / \mathrm{sec}$ near the surface to $6.2 \mathrm{~km} / \mathrm{sec}$ at 60 meters into the basalt (Figure 3 ). There are pronounced changes in composition with depth (Kempe, this volume, Chapter 14), and also an apparent decrease in weathering downward. The samples used for the laboratory measurements were selected to be the least weathered in a short section (because of other measurement requirements) so the $0.5-\mathrm{kb}$ laboratory values are slightly biased to high velocities. The shipboard 1-atm samples were taken roughly at uniform intervals so have no systematic bias and give a truer representation of the trend with depth. Site 257 is into approximately 100 m.y.-old basement so the weathering would be expected to have penetrated to a considerable depth. The other holes on Leg 26 were too shallow to define a trend with depth well. However, there is an indication of a rapid increase in velocity with depth for the younger holes, 
TABLE 1

Seismic Velocities Under Pressure

\begin{tabular}{|c|c|c|c|c|c|c|c|c|c|}
\hline \multirow{2}{*}{$\begin{array}{c}\text { Sample } \\
\text { (Interval in cm) }\end{array}$} & \multirow{2}{*}{$\begin{array}{l}\text { Depth into } \\
\text { Basalt (m) }\end{array}$} & \multirow{2}{*}{$\begin{array}{c}\text { Density } \\
(\mathrm{gm} / \mathrm{cm})\end{array}$} & \multicolumn{4}{|c|}{ Velocity $(\mathrm{km} / \mathrm{sec})$} & \multicolumn{3}{|c|}{ (Pressure, psi $\times 1000)$} \\
\hline & & & 2.5 & 5 & 7.5 & 10 & 15 & 20 & 30 \\
\hline $\begin{array}{l}250 \mathrm{~A}-26-2,140 \\
250 \mathrm{~A}-26-6,58\end{array}$ & $\begin{array}{r}6.60 \\
11.78\end{array}$ & & $\begin{array}{l}6.13 \\
6.02\end{array}$ & $\begin{array}{l}6.17 \\
6.09\end{array}$ & $\begin{array}{l}6.22 \\
6.17\end{array}$ & $\begin{array}{l}6.22 \\
6.17\end{array}$ & $\begin{array}{l}6.32 \\
6.24\end{array}$ & $\begin{array}{l}6.32 \\
6.24\end{array}$ & $\begin{array}{l}6.32 \\
6.24\end{array}$ \\
\hline $\begin{array}{l}251 \mathrm{~A}-31-2,84 \\
251 \mathrm{~A}-31-3,50 \\
251 \mathrm{~A}-31-4,48 \\
251 \mathrm{~A}-31-5,105\end{array}$ & $\begin{array}{l}2.84 \\
4.00 \\
5.48 \\
7.55\end{array}$ & $\begin{array}{l}2.82 \\
2.86 \\
2.93 \\
2.94\end{array}$ & $\begin{array}{l}5.55 \\
6.31 \\
5.94 \\
5.93\end{array}$ & $\begin{array}{l}5.61 \\
6.49 \\
6.05 \\
6.01\end{array}$ & $\begin{array}{l}5.61 \\
6.49 \\
6.13 \\
6.06\end{array}$ & $\begin{array}{l}5.68 \\
6.58 \\
6.17 \\
6.15\end{array}$ & $\begin{array}{l}5.68 \\
6.62 \\
6.25 \\
6.24\end{array}$ & $\begin{array}{l}5.68 \\
6.62 \\
6.29 \\
6.33\end{array}$ & $\begin{array}{l}5.76 \\
6.77 \\
6.37 \\
6.33\end{array}$ \\
\hline $\begin{array}{l}254-31-1,111 \\
254-35-1,107 \\
254-36-3,105\end{array}$ & $\begin{array}{c}\text { sill } \\
14.07 \\
22.05\end{array}$ & $\begin{array}{l}2.74 \\
2.75 \\
2.82\end{array}$ & $\begin{array}{l}5.20 \\
4.79 \\
5.24\end{array}$ & $\begin{array}{l}5.40 \\
4.92 \\
5.30\end{array}$ & $\begin{array}{l}5.52 \\
4.97 \\
5.36\end{array}$ & $\begin{array}{l}5.56 \\
5.02 \\
5.42\end{array}$ & $\begin{array}{l}5.65 \\
5.07 \\
5.48\end{array}$ & $\begin{array}{l}5.65 \\
5.07 \\
5.48\end{array}$ & $\begin{array}{l}5.73 \\
5.13 \\
5.55\end{array}$ \\
\hline $\begin{array}{l}256-10-2,68 \\
256-10-3,85\end{array}$ & $\begin{array}{l}10.18 \\
11.85\end{array}$ & $\begin{array}{l}2.96 \\
2.96\end{array}$ & $\begin{array}{l}5.67 \\
6.23\end{array}$ & $\begin{array}{l}5.84 \\
6.38\end{array}$ & $\begin{array}{l}5.88 \\
6.47\end{array}$ & $\begin{array}{l}5.96 \\
6.47\end{array}$ & $\begin{array}{l}6.04 \\
6.56\end{array}$ & $\begin{array}{l}6.04 \\
6.56\end{array}$ & $\begin{array}{l}6.12 \\
6.65\end{array}$ \\
\hline $\begin{array}{l}257-11-2,74 \\
257-12-1,130 \\
257-12-3,35 \\
257-13-3,15 \\
257-14-2,95 \\
257-15-1,133\end{array}$ & $\begin{array}{r}3.24 \\
11.80 \\
13.85 \\
23.15 \\
30.45 \\
37.33\end{array}$ & $\begin{array}{l}2.74 \\
2.73 \\
2.73 \\
2.82 \\
2.75 \\
2.89\end{array}$ & $\begin{array}{l}5.06 \\
5.97 \\
5.88 \\
5.46 \\
5.15 \\
6.04\end{array}$ & $\begin{array}{l}5.18 \\
6.06 \\
6.02 \\
5.53 \\
5.21 \\
6.13\end{array}$ & $\begin{array}{l}5.21 \\
6.11 \\
6.13 \\
5.60 \\
5.27 \\
6.13\end{array}$ & $\begin{array}{l}5.24 \\
6.11 \\
6.20 \\
5.60 \\
5.27 \\
6.22\end{array}$ & $\begin{array}{l}5.31 \\
6.25 \\
6.28 \\
5.67 \\
5.33 \\
6.22\end{array}$ & $\begin{array}{l}5.38 \\
6.35 \\
6.35 \\
5.67 \\
5.33 \\
6.22\end{array}$ & $\begin{array}{l}5.45 \\
6.35 \\
6.43 \\
5.73 \\
5.39 \\
6.31\end{array}$ \\
\hline
\end{tabular}

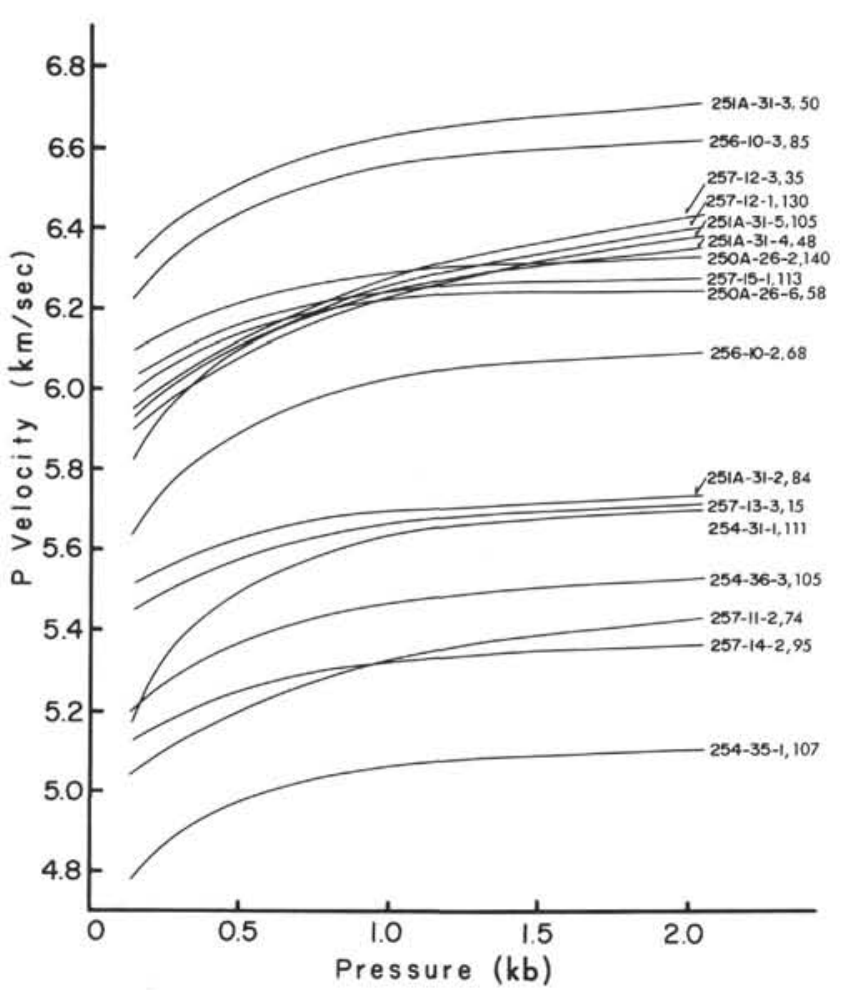

Figure 1. Compressional velocities of Leg 26 basalts as a function of pressure.

consistent with a slow downward diffusion of weathering (Figure 4). On previous legs a deep basalt hole at Site 238 (about 35 m.y.) showed no trend with depth and a high mean velocity of about $5.8 \mathrm{~km} / \mathrm{sec}$ while older sites such as Sites 236 (about 55 m.y.), 231, and 235 do show systematic increases with depth.

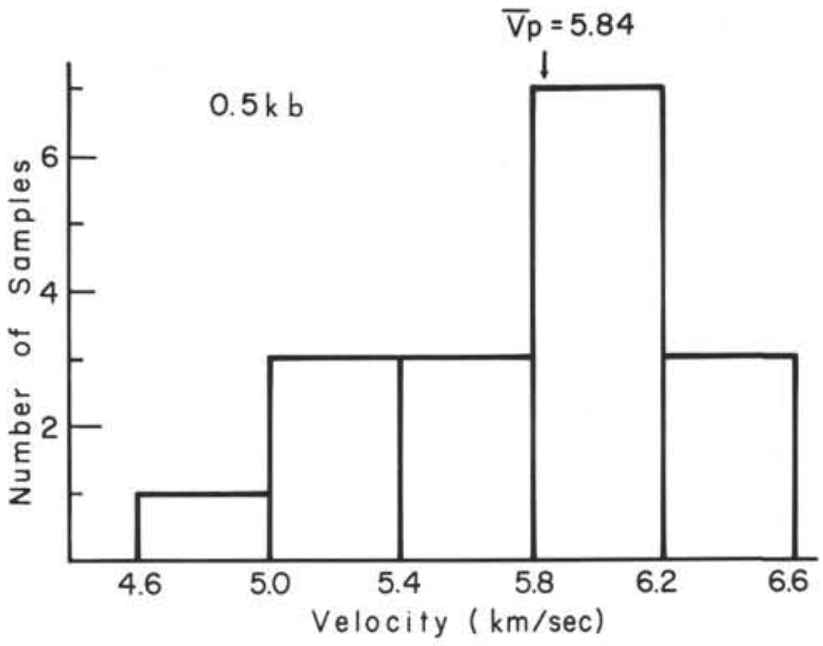

Figure 2. Histogram showing the number of samples as a function of velocity at $0.5 \mathrm{~kb}$ pressure.

Christensen and Salisbury (1972) and Christensen (1973) show that there is a continuous decrease in velocity and in density with age of sea-floor basalts that they associate with slow weathering. Recent extensive measurements (N. I. Christensen, personal communication) clearly define the correlation. The rate of weathering is consistent with observed chemical changes (Hart, 1970, 1973; Hekinian, 1971) and with a decrease in density of $0.15 \%$ per m.y. Ryall and Ade-Hall (1973) found that weathering alteration as it affects the magnetic properties of the rocks (Curie temperature and saturation magnetization and NRM) progresses slowly through basalt pillows. Only the very surficial $1 \mathrm{~cm}$ or less is significantly altered in a 12,000-year-old pillow, while the alteration had extended to increasing depth in older samples and had penetrated over $10 \mathrm{~cm}$ into a 
TABLE 2

Shipboard Velocity Measurements at One Atmosphere of Pressure

Using the Hamilton Frame

\begin{tabular}{cll}
\hline $\begin{array}{c}\text { Sample } \\
\text { (Interval in } \mathrm{cm})\end{array}$ & $\begin{array}{l}\text { Depth into } \\
\text { Basalt }(\mathrm{m})\end{array}$ & $\begin{array}{l}\text { Velocity } \\
(\mathrm{km} / \mathrm{sec})\end{array}$ \\
\hline
\end{tabular}

Hole 250A

$\begin{array}{ll}26-1,60 & 4.30 \\ & \\ 26-2,110 & 6.30 \\ 26-3,60 & 7.30\end{array}$

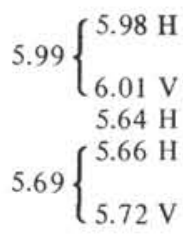

Hole 251A

$\begin{array}{lll}31-2,100 & 3.00 & 5.28\left\{\begin{array}{l}5.24 \mathrm{H} \\ 5.33 \mathrm{~V}\end{array}\right. \\ 31-3,50 & 4.00 & 5.76\left\{\begin{array}{l}5.76 \mathrm{H} \\ 5.77 \mathrm{~V}\end{array}\right. \\ 31-5,100 & 7.50 & 5.63\left\{\begin{array}{l}5.69 \mathrm{H} \\ 5.57 \mathrm{~V}\end{array}\right.\end{array}$

Site 254

$\begin{array}{lcr}31-1,110 & \text { sill } & \begin{array}{r}5.75 \mathrm{H} \\ 5.31 \mathrm{~V}\end{array} \\ 35-1,50 & 9.50 & 3.65\left\{\begin{array}{l}3.58 \mathrm{H} \\ 3.72 \mathrm{~V}\end{array}\right. \\ 35-2,40 & 10.90 & 4.97\left\{\begin{array}{l}4.96 \mathrm{H} \\ 4.99 \mathrm{~V}\end{array}\right. \\ 35-3,20 & 12.20 & 5.05\left\{\begin{array}{l}5.06 \mathrm{H} \\ 5.05 \mathrm{~V}\end{array}\right. \\ 36-2,30 & 15.80 & 4.15\left\{\begin{array}{l}4.15 \mathrm{H} \\ 4.15 \mathrm{~V}\end{array}\right. \\ 36-3,20 & 17.20 & 4.65\left\{\begin{array}{l}4.56 \mathrm{H} \\ 4.75 \mathrm{~V}\end{array}\right. \\ 36-3,110 & 18.10 & 5.26\left\{\begin{array}{l}5.28 \mathrm{H} \\ 5.25 \mathrm{~V}\end{array}\right.\end{array}$

Site 256

$\begin{array}{lcc}9-2,50 & 0.50 & 4.85\left\{\begin{array}{l}4.95 \mathrm{H} \\ 4.75 \mathrm{~V}\end{array}\right. \\ 9-3,45 & 1.95 & 5.93\left\{\begin{array}{l}5.98 \mathrm{H} \\ 5.88 \mathrm{~V}\end{array}\right. \\ 9-3,130 & 2.80 & 5.84\left\{\begin{array}{l}5.85 \mathrm{H} \\ 5.84 \mathrm{~V}\end{array}\right. \\ 10-2,105 & 10.55 & 5.62\left\{\begin{array}{l}5.67 \mathrm{H} \\ 5.58\end{array}\right. \\ 10-4.140 & 13.90 & 6.22\left\{\begin{array}{l}6.13 \mathrm{H} \\ 6.29 \mathrm{~V}\end{array}\right. \\ 11-2.60 & 16.60 & 4.93\left\{\begin{array}{l}5.00 \mathrm{H} \\ 4.86 \mathrm{~V}\end{array}\right. \\ 11-3.110 & 18.60 & 5.43\left\{\begin{array}{l}5.33 \mathrm{H} \\ 5.53 \mathrm{~V}\end{array}\right.\end{array}$

Velocity $(\mathrm{km} / \mathrm{sec})$

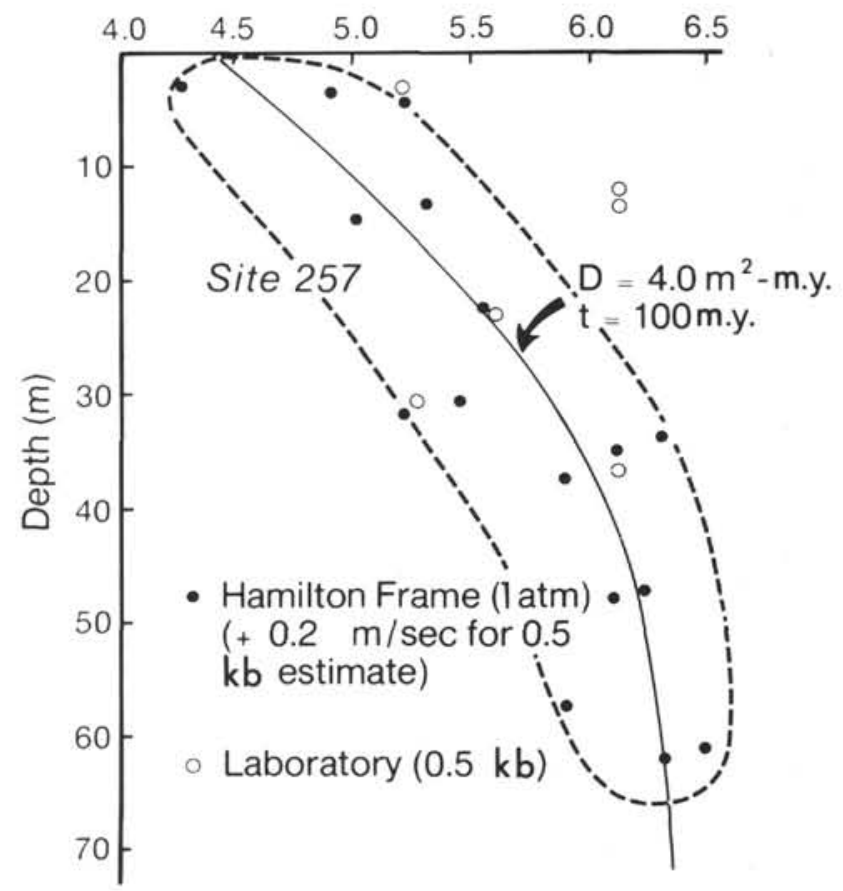

Figure 3. Variation of basalt velocity with depth in Site 257. $0.2 \mathrm{~km} / \mathrm{sec}$ has been added to the $1 \mathrm{~atm}$ measurements to approximate the velocities at $0.5 \mathrm{~kb}$.

740,000 -year-old pillow. The results may be viewed as the diffusion of alteration downward into the crustal rocks. On a larger time scale Ade-Hall (this volume, Chapter 19) has shown that Site 257 the 100-m.y.-old basalts have similar alteration extending to a depth of about 30 meters. If the decrease in velocity with age for the near-surface samples of Christensen and Salisbury (1972) arises from the same alteration process as the magnetic changes, the velocity in this hole should increase with depth to values characteristic of young shallow samples.

If the weathering process follows a simple downward diffusion of seawater, the diffusion constant for Site 257 is about $4.0 \mathrm{~m}^{2} / \mathrm{m} . y$. (Carslaw and Jaeger, 1959). This rate of diffusion is much faster than that indicated for single lava pillows (Ryall and Ade-Hall, 1973) so the downward movement of seawater must depend largely on cracks and fissures rather than on simple diffusion through the rock. The process is undoubtedly complex, perhaps with different weathering rates depending on the extent of fracturing and on the presence or absence of a sediment cover.

The data suggest that the decrease in velocity with age for refraction measurements (Le Pichon et al.,1965) and for shallow samples (Christensen and Salisbury, 1972) only refers to a thin weathered-surface layer. This layer thickens with age. Deep old samples will have the same high velocity as shallow young samples. The mean velocity of Layer 2 may be higher than previously thought; likely, at least $5.8 \mathrm{~km} / \mathrm{sec}$. 


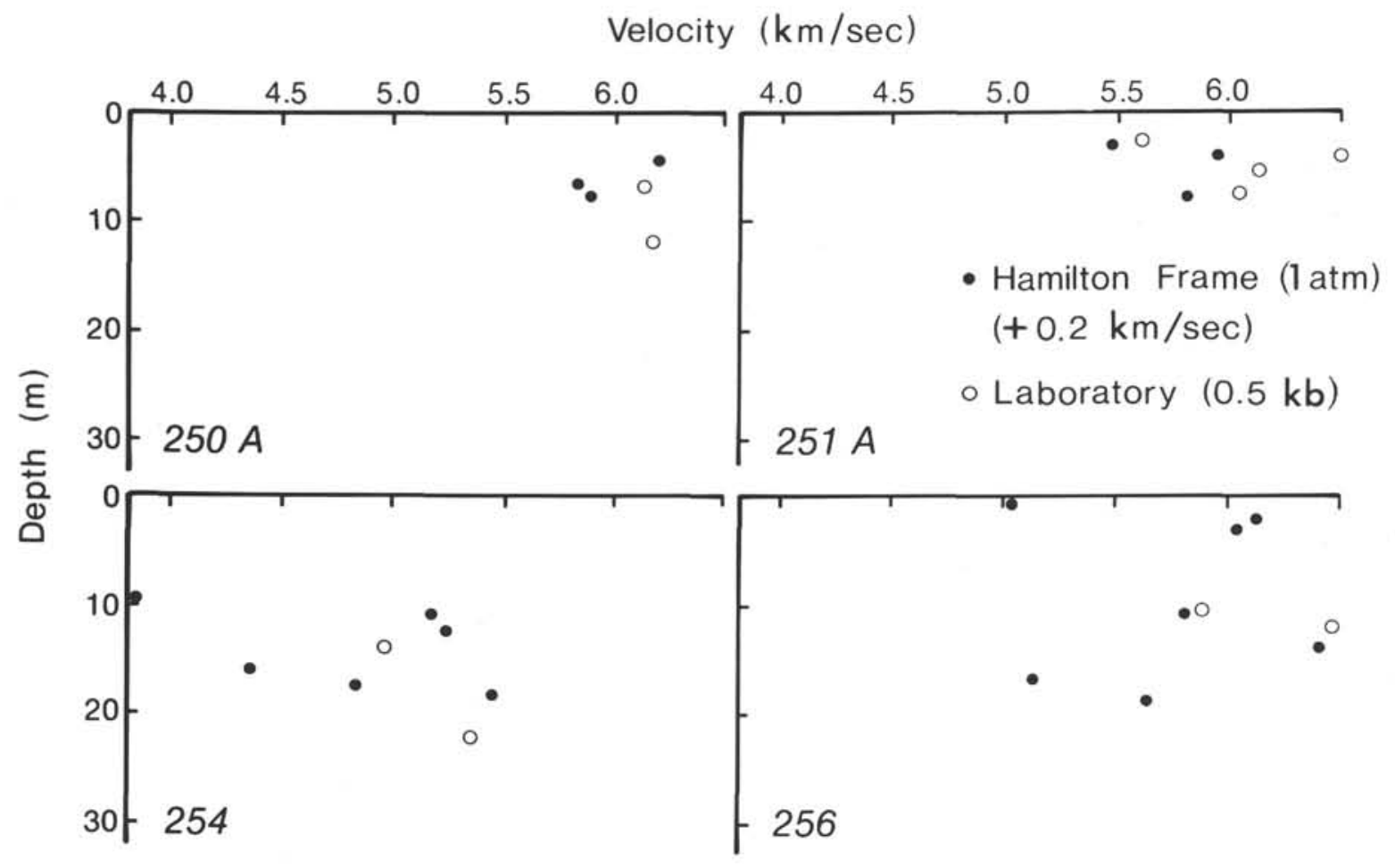

Figure 4. Variation of basalt velocity with depth in Sites 250A, 251A, 254, and 256.

\section{REFERENCES}

Barrett, D. L. and Aumento, F., 1970. The Mid-Atlantic Ridge near $45^{\circ} \mathrm{N}$. XI. Seismic velocity, density and layering of the crust: Canadian J. Earth Sci., v. 7, p. 1117-1124.

Birch, F., 1960. The velocity of compressional waves in rocks to $10 \mathrm{~kb}$, Part 1: J. Geophys. Res., v. 65, p. 1083-1102.

1961. The velocity of compressional waves in rocks to 10 kb, Part 2: J. Geophys. Res., v. 66, p. 2199-2224.

Carslaw, H. S. and Jaeger, J. C., 1959. Conduction of heat in solids, 2nd Ed.: London (Oxford Univ. Press).

Christensen, N. I., 1973. Compressional and shear wave velocities and elastic moduli of basalts, Deep Sea Drilling Project, Leg 19. In Creager, J. S., Scholl, D. W., et al., Initial Reports of the Deep Sea Drilling Project, Volume 19: Washington (U.S. Government Printing Office),p. 657-659.

Christensen, N. I. and Salisbury, M. H., 1972. Sea floor spreading, progressive alteration of layer 2 basalts, and associated changes in seismic velocities: Earth Planet. Sci. Lett., v. 15, p. 367-375.

Christensen, N. I. and Shaw, G. M. 1970. Elasticity of mafic rocks from the Mid-Atlantic Ridge. Geophys. J., v. 20, p. 271-284.

Fox, P. J., Schreiber, E., and Peterson, J. J., 1972. Compressional wave velocities in basalt and altered basalt recovered during Leg 14 . In Hayes, D. E., Pimm, A. C., et al., Initial Reports of the Deep Sea Drilling Project, Volume 14, Washington (U.S. Government Printing Office), p. 773-775.
1973. The Geology of the Oceanic Crust: Compressional Wave Velocities of Oceanic Rocks: J. Geophys. Res., v. 78, p. 5155-5172.

Hart, R. A., 1970. Chemical exchange between seawater and deep ocean basalts: Earth Planet. Sci. Lett., v. 9, p. 269-279.

1973. A model for chemical exchange in the basaltseawater system of oceanic layer II: Canadian J. Earth Sci., v. 10 , p. $799-816$.

Hekinian, R., 1971. Chemical and mineralogical differences between abyssal hill basalts and ridge tholeiites in the eastern Pacific Ocean: Marine Geol., v. 11, p. 77-91.

Le Pichon, X., Houtz, R. E., Drake, C. L., and Nafe, J. E., 1965. Crustal structure of the mid-ocean ridges: J. Geophys. Res., v. 70, p. 319-339.

Ludwig, W. J., Nafe, J. E., and Drake, C. L., 1971. Seismic refraction. In Maxwell, A. E. (Ed.), The sea, v. 4, New York, (Interscience), p. 53-84.

Raitt, R. W., 1963. The crustal rocks. In Hill, M. N. (Ed.), The sea: v. 3, New York, (Interscience), p. 85-102.

Ryall, P. J. C. and Ade-Hall, J. M., 1973. Magnetic properties and submarine weathering in pillow lavas. (Abstract): Am. Geophys. Union Trans., EOS, v. 54, p. 244.

Schreiber, E., Fox, P. J., and Peterson, J. J., 1972. Compressional sound velocities in semi-indurated sediments and basalts from Deep Sea Drilling Project Leg 11. In Hollister, C. D., Ewing, J. I., et al., Initial Reports of the Deep Sea Drilling Project, Volume 11, Washington (U.S. Government Printing Office), p. 723-727. 